\title{
X. Cursory Geological observations lately made, in Shropshire, Wales, Lancashire, Scotland, Durham, Yorkshire NR., and Derbyshire. Some observations on Mr. Bakewell's Geological map, and on the supposed identity of the Derbyshire Peak and the Craven Limestone Rocks, \&c. \&c.
}

\section{Mr. John Farey Sen.}

To cite this article: Mr. John Farey Sen. (1813) X. Cursory Geological observations lately made, in Shropshire, Wales, Lancashire, Scotland, Durham, Yorkshire NR., and Derbyshire. Some observations on Mr. Bakewell's Geological map, and on the supposed identity of the Derbyshire Peak and the Craven Limestone Rocks, \&c. \&c. , Philosophical Magazine Series 1 , 42:183, 53-59, DOI: 10.1080/14786441308638281

To link to this article: http://dx.doi.org/10.1080/14786441308638281

Published online: 27 Jul 2009.

Submit your article to this journal $\pi$

山 Article views: 5

Q View related articles $\sqsubset$

Citing articles: 1 View citing articles ¿ð 
X. Cursory Geological Olservations lately made, in Shropshire, Wales, Lancashire, Scotland, Durham, Yorkshire NR., and Derbyshire. Some Observalions on Mr. Bakew'ell's Geological Map, and on the supposed Identity of the Derbyshive Peak and the Craven Limestone Rocks, ơc. Ëc. By Mr. John Farey Sen.

\section{To Mr. Tilloch.}

SIR,-I have for a long period been prevented from communicating to your useful work, although I have frequently in the interval been reminded by my friends, that a letter in your xith vclume, p. 45, required an answer from me.

Several weeks before this letter appeared, I left home, spent two or three days near Ludlow, in examining the Clee Hills to the E, and the two Limestone Rocks (besides that under Clee Hills) which I found ranging on the west and north-west sides of that 'Town. From hence I proceeded to Hafod, and spent several days in examining the strata and ranges of the Cum-ystwith and several others of the Mireral Veins of that curious district. I then proceeded by Aberystwith, Shrewsbury, Liverpool, Kendal, and Carlisle, to Edinburgh, where I took a hasty view of Arthur's Seat and a few other objects in the vicinity, and then proceeded for Perth, Aberdcen, Banff, Fochabers, Nairn, and Inverness, where I spent a day in examining the excavations for the eastern end of the Caledoniau Canal, \&c. and then went through Tain and Dornoch to Dunrobin Castle, in whose neighbourhood I spent several weeks, examining the strata thence into Caithness, and as far SW as Bonar Bridge, and particularly within the Coal. fic $l l$, which has been worked* since 1598 , with some intervals, and was lately resumed (Phil. Mag. vol. xxxix. p. 337), on the banks of the Brora River, near its mouth.

On my return, I caine by sea to Banff, spent a day there, and examined the coarse slate on the shore near MacDuff and that Town, then again through Aberdeen and Bervie to Perth : here I spent two days examining Kinnoul Hill, \&c.

* In Edinhurgh, the hot-bed of Geological speculation and contention, a learned Doctor lately edited a 2d edition of the late Mr. John Williams's very valuable work on the "Mineral Kingdom," and has affixed a Life of the Author, wherein he has shown his ignorance of the fact, that Mr. Williams was for several years prior to 1770 , the Lessee under the Earl of Sutherland, and worker of these Coal-pits fulthough in his work Mr. W. scarcely alludes thereto), and the Doctor strongly insinuates, if not asserts, there are no Coals in Sutherland! 


\section{Mr. Farey's Geological Olservations in Durham, \&ic.}

whose massive strala appear to me to form part of the continuous erige of Basalt, stretchitic (generally with a north: western dipl I believe) from near Montrose on the German Ocean, to Dunbarton on the Clyde, (and verhaps thence across Arran, \&ce to Rolblin and Antrim?) covering and liming the great Coal-field of the Forth and Clycte; great part of which, it seems once to have covered, before the vast and complicated denudations were performed, which bave in many parts cut deep into the Coal measures, and left numerous detached Hummocks of Pasalt, like that of Arthur's Seat, and all others which I saw thence to near Kinrors.

From Edinburgh I returned by Haddington, Dunbar, Berwick, and Befford, to Newcastle; a day which I spent here was lost as 10 any observations on the strata, owing to a disıral thick fog : next day I was more fortunate at Sunderland and Durham : at West Bolden, I lett the Coalmeasures and ascended the regular edge of the lower yellow Limestone Rock, which I at once recounised, and descended it again a mile NE of Houghton le Spring. At Ferry Hill I again ascended the edge of the lower yellow Limestone Rick, and was there hospirably enterrained and much instructed, by Mr. Thomas Arrowsmith, whoworks a colliery through the lower Limestone Rock, as at Parlington, Knitaker, Skeghy, Nuthall, Biborough, \&c. are or has been done, Derb. Rep. i. 156, and Phil. Mag, vol. xxxix. p. 99 and 103 . South of Ferry-Hill, I soon ascended an indistinct edge of the Red Marl between the Limestone Rocks, such as had often deceived me in Notts. and Derbyshire, as mentioned Phil. Mag. vol. xxxix. p. 104, and then the edge of the upper Yellow Limestone, which dips into a trongh at Rushyford, and is there covered by $a$ clayey soil (jerhaps alluval $)$, which trongh and covering stratum, seems to me from "my inquiries, to extend enstward by Sedgefield, or sonth of it, to the coast SW of Harilepool; but these are points on which I am extremely desirous of precise information from your Correspondents.

On the $S$ of Aycliff I again descended the edge of the upper Rock, and came upon the Red Marl, here not am. bigmus or doubtful, being thicker than at Fairburn (Phil. Mag. vol xxxix. p. 104), and therean (or its imbedded gritstone) I travelled, through Darlington, Croft, North-Cawton, Catterick-Bridge, Leeming, and Ripon; soon after which, I descended again on to the top of the lower yel. low Lime Rock (left on the S of Ferry Hill), and afier seeing several large Lime-works therein, which stretch 
NNW and SSE for many miles, as I was told, I obliquely descended the edge of this lower Rock, passed through Ripley, and was proceding on Coal-measures towards High Harrowgate, when unfortunately it grew dnsk, and singlt socm prevonted my seeing the very interesting country thence to ILeeds, as it had previously done through several miles of my approach to Newcastle, and to Perth in my return, and to Nairn, and to Bank-house in the southern extremity of Edinburgh county, in my way North : interruptions to the course of my Observations, which $I$ much fament, but could not avoid without the loss of a day in each case (which I coukd not spare) and much extra expense for post-chaises, which I always avoid, also, when I can obtain a much more favourable seat for observation on a mail or stage coach, with the privilege secured, of a seal inside in case of night coming on, or of rain, \&c. which would prevent the constant recording of my observations.

From Leeds I hastened to Ashover, and with my son's assistance (William F.) who bad previously resumed the Survey of Ashover and its vicinaty, (that we began in the preceding year) by the mixidle of November, we had so far proceeded, that a Report therem could be made up, my Maps copied, \&cc. * which, and those relating to my Suther. land

* I have great reason now to wish, that 1 could recall or expunge the Jast paragraph in page ix of the preface to vol. ii. of my Derby Report, published in Fobruary last: a paper, of $1 \% 0$ closely written folio pages having been prepared by me, under the advice and copied after the repeated perusal of G. B. Greenough, Esq. the late President of the Geological Society, was presented through him to that Body on the 4th of February last, accompanied by a Mincial Map, filled up with the strata of more than thirty square mites including Ashover, on a scale of $1 \frac{1}{2}$ inch to a mile; these were in addirion, and by Mr. G.'s desire prepared, for explaining a large Section from actual aurver, of the strata for more than seven miles in length of sirface, crossizg Ashover, and an attached and corresponding Map of the strata and every object on the surface, half a mile wide, on a scale of 10 inches to $a$ mile, which Section had been contitionally presented and left with the Society since March 1812 , by desire of Sir Josept Banks, Bart, formerly a member thereef.

I heard nothing from the Society, until towards the end of April, when I reccived a Letter acknowledging (according to a printed form) the receipt of my papcr, \&c. and a few days after there appeared in yours and the Journal of Mir. Nicholson, a similar paper (sent officially as I have been informed) from the Geological Society, as a Report of their proceedings. About a month after this, in consequence of a remonstrance on my part to Mr. G. on some reports and circumstances of a novel kind that had reached nie, regarding my paper and Maps, he introduced a Geutleman to me, who a short time after called on me, and among other thiugs told me, that the forth-coming volume of the Society's Transactions was intrusted to him, and nothing would appear therein but what he approved; that the ideas of the Council were averse to the publication of my paper, he believed he could 


\section{Mr. Farey's Geological Observations in Scotland, \&ో.}

land business and other urgent matters, have occasioned the interrupions to my occasional contributions, through your valuable work, towards the knowledge of the stratification ot the British I ileti.

Before anv leisure occurred to me for adverting to $\mathrm{Mr}$. Bakrwell's Letter in your Number for wily 1812, he had ann.unced his being engaged on an "Introduction to Geology," and I have since "aited until I could give a very attent ve reading to his Book. Now we are more fairly at issue, on the points in cur Letters in your xxxixth vol. p. 425 , and xlth vol. p. 45.

The precise nature of Mr. B's original "Geological Map of England" is now seen, in his 4th plate. As an "Outline"

say 80 of every individual theren $f$, of this fact he produced however $n n$ pronf. nor have I the opportunity to the present hour of learuing in a regular way, any "pinion or decision whatever "f the Council (much less of the Suciety) respecting my Paper, Section, or Maps, or the nature of the objections that have privalely been raised to any parts of either!

This learned Editur and caterer for the Geological taste, went on to persuade me, that he himself was a well wisher to my pursuits and communications (with what truth the circumstances best tell) and had thc; efore taken immease pains to uritt a new paper for me, which afier perusing (as I did with great care) I would do well he said to adopt and allow my signature to be placed as my original communication! I scarcely need say more, to convey an idea of this performance, to my Friends, who know the foits of Derbyshire and its strata, than that the Report in the Phil. Mag. vol. xli. p. SOS to $\mathrm{OS}$, and its many misconceptions and blunders, was made from this Edit'r's Paper, instead of my original paper; and perhaps this only was Read (not on a regular meeting day) instead of $\mathrm{my}$ original paper? The above fact as to the original of the printed Report, appeared clearly to me, from their perfect coincidence in the erroneous points.

On my objecting to this course to Mr. Editur, and attempting to show, that the first part of my paper (near half of $i$ and by far the most impurtant part) would be injured greatly by the total change of arrangement and inordinate compresion it had suffered (the Roport on this part is accordingly compressed into 4 lines, p. 303), and nly Mineral Map greatly spoiled by the alieration (from whim only, as far as I could learn) that was insisted on therein I was coolly told, that the Serreiaries would immediately return my papers, if I applied fir them; and so they did, on the 2 ist of June, without the least explanation of or apology for, the extraordinary circumstances pointed out to them or referred $t o$, in my Letter of the $19: \mathrm{h}$ of June. I have not at tempted to quote the prectse wurds which passed on the above unprecedented and disagreeable occasions, but to give the substance, as concisely and as correctly as I could.

It appeared unnecessary above, in referring my Derbyshire Friends to the Geolugical Report on my paper, $p$ 309, vol xli. to staie, that the loose and indpplicable Anglo-Wernerion tormis therein, were not used by me, but some of them expressly disclaimed in my paper as being contrary to more proper terms, previursiy in use among Engusl. Geologists, and to which I adhered: this was in consequence, of being actually told by an individual Member of the Geolugical ouncil, while my paper was in hand, that if l did not use Wernerian lernis nobndy uould read my poper? It was raiher unfortunate, that I could not then see the full impert of this hint, and have avoided the loss of many weeks of my time this spring, and some subsequent vexation. 
it is rather naterially incurrect in two or three places: viz. to the north and north-east of York, the Oalite Limestone, so di-tinctly described in your $x \times x i x t h$ vel. pages $9 i$ and 98 , is omitted in the "low district," a name of his, which certainly ill befis this elevatrd Limestone tract. Mr. B's Alpins or "Devonian Range" of Primitice and Transition Rucks, has been carried a griat many miks tou far to the north east, on the shore of the Bristol channel, as Mr. B. might have learnt, from Mr. Wm. Smuth's Report on the Nailsea Coalfullt, \&c. in your $\times x \times$ viuth voi. p. 32 ! ; had not this Genleman, and his purssits, bes'n denied all mention of even allusion, in thik work, containing so much "original information" (page $x i$ ), and whose arrangement of particulars on the Geolugy of Einsland, had not "been before noticed" (j. 13).

Mr. B. seems not aware, that the Chalk extends, on and near to the south Coast. considerably to tise west of his "low district," and that the large tract called Blackdown, is covered by Sand, \&c. from under the Chalk, very different from any thing in his " middle district," as he night have gattered trom Mr. James Sowerby's "Mineral Concholngy," pages 4', 57, 58, 60, \&c. The inhabilants of Exeter and all its vicinity, "nuid dombtless be nuch obliged to Mr. B., if he could find there, the characteristic minerals of his " middle district," viz. "coal", iromstone, and rock-salt," (p. 274 and 11 ).

The Flintshire Coal-field on the SW shore of the Dee is not shown, although mentioned, p. 295, nor that of Anglesea (alluded in p. 275 note.) of uhose situation (on the Cefini Rivil) be might bave learned sumething, from Mr. Aikm's Puur, p. 132, and Mr. Parkinsm's Ory. Rem. i. 178.

In Mr. B's " nurthern Alpiue range," sonie of the small Coal lasins or Swilleys occur, it hich / have mentioned in your $x \times x$ ixith vol, p. $30 \mathrm{Nole}$, and had I lime, I could I think nention several Collieries in different and more central parts, of this primitine and transition tract of $\mathrm{Mr}$. B.

Mr. B asserts, p. 264, that "no metallic vcins" are found cast of his line C C C, in any part of England. At pagis 254 and 270 and 407 of the Deiby Rep. vol. I. I have mentioned two contrary instances, anisther is mentioned in your

- The $W^{*}$ is Coal of Bovey, occurring, as is very usual with this substance, " in alluvial ground," $p 141$, "separated by straia of clay and gTarel," p. 159, underlaid (as I have heard) by alluvial sand and gravel, on a discrict of poarse Slate, has do precensions to rank with the regular Coul-fields of the "middle district," wherein slate has no place, being a "Transition" Rock, P. \$8. The Coal of Portland Isle and Kimeridge, seem to have better clains to be placed in the middle disicict, than that of Bovey has. 
zxxixth vol. p. 498, and I could I think from other districts, increase the list. What Mr. B. calls "subterranean" Forests, p. 11, 205 , and 269 , viz. stumps of Trees buried in peat, are not peculiar to the Lincolushire and Yorkshire Coast, or even to his "bow distric," but in every situation from the Laind's-end to John o" Groats", on both sides of the Island; on flat shores which have neither wasied or increased by the action of the currents, in modern times, the same phenomenon and athers nccur, inclicative of the gradual rise of the Sea. In Sutherland this is proved, by the waves having lately covered with Beach, the hillocks of Coal-pits worked in Queen Elizabeth's Reign. In the Manuseripts of the Jate ingenious Leciurer, Mr. Waltire, his observations on this phenomenun, on the various Coasts of Engiand, and also of Holland, which he went to examise, are dotailed, as $I$ have been informed. Westminster Hall, Boston Cburch, and perhaps other fine old buildings, being now often Alooded some feet deep by the increasing tickes, furnish other proofs of the same thing.

The contemptuous boast by Mr. B. (p. 45 of your xlth vol.) of his ignorance of what Mr. Smith may have done, towards a Map of the Strata of England. (for as to faults, he had ro ground for coupling me and Mr. Smith, as appears from your xxxvith vol. p. 441) surely does not seem much calculated to raise his character as a philosophical enquirer after truth, or as a liberal historian of the labours of his cotemporaries*, to say nothing of the interes!ed views which might be taken of such conduct, trom one protescional man towards another.

I am extremely happy, however, to be able to state, that the public are not likely to remain long ignorant of $\mathbf{M r}$.

* Mr. B's eagerness to renew his atiacki on the suljuct of Faulls (p. 2 ls and 283 ) would not permit him to appear totally to coverlesok me as he has chone Mr. Smith, and it is not unworthy of remark, that in the only instance in which I am expressly referred to, for a single Geological fact or inference, it has beendune in an unfair way.-After the account of the Derbyshire Mineral Veins bad been written far my Report, Mr. Joshna Gregory, the very able and respectable overseer of the Gang Mine near Wirksworth. happening to be in town, I either read or related to him all the most material points therein; on which occasion, and atter I had any opportunity of making inquities of ather Winers thronghint tha' rounty, as in most, if not on ever yother inatetial point was expresily done; Mr. Greosry atated, th:t "some

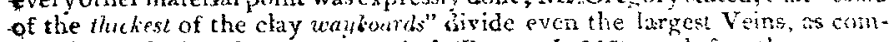
pletely as the Toadstene strita do" (Report 1. 24,5), and for the redons above stated, I added, "as I am informed by Mr. Johliun Gregory, an experienced twiner." Yet Mr. B. p. 226, thus refers to the passage. "Mr. Farey" soys, "that where the beds of lime-stunc are divided by scams of clay, these ceams fremently cut off the vein is efiectually as the thick beds of Toadtone," omitting alt mention of Mr. Gregury, or his and my distinction, that only "some of the thickest" wayboards, were here spokcn of.

Sinith's 
Smith's meritorious labours on this important subject, since Mr. John Cary of the Sirand has the publication now in hand, and the greater part of a Map of Engrland, Wales, part of Scotland, France, and Ireland (for the sake of shewing the connections of strata) is already engraved, on a scale of 5 miles to an inch, for Mr. Smith's intended publication.

Mr. B. will I conceive find it d:ficull to shew, that I have asserted that the metalliferons limestone in the singular) in Derbyshire is the very lowest stratum of Rocks in England: for although to sut the purposes of the transition part of his new Theory, Mr. B. chuses always to speak of the four regular calcareous Rocks, which Mr. Whilehurst and myself have described in the Peak Hundreds, as one Ruck, yet this won't prevent our seeing, that should the top of the first or upper of these Rocks be proved to appear from under Shale-grit and Millstone-grit near Burnsal (as I rather believe it does;, yet that the top of the second, the third and the fourh of these Rocks in succession, and more so the lottom of the last or lowest of them, in short the whole series appearing in Craven or near it, may still safely be doubted, since no new light is thrown, or confirmation offered in Mr. B's recent work, of such his opinion; it is true he has "repeated the assertion again," at pages 274 , 279 and 281.

After having seen the different ranges of Limestone between Lancaster and Kendal, overlieing a Slate, which $\mathrm{Mr}$. B. has admitted to be the same Slate with that of Craven; 1 have now better reasons than when I first wrote, for agreeing with Mr. Mushet (vol. xl. p. 53) in thinking these to be very different Rocks from any in the north of Derbyshire; and to me they seemed, well to answer to the Rocks 1 had observed $W$ and NW of Ludlow (as already mentioned herein) and had more recently crossed when again leaving the slate, near to Welsh-pool, in my return from Wales.

$\mathrm{Mr}$. B's assertion, that I had nothing to advance in support of my opinion; as to the Peak and the Craven Limestones, but the existence of my "imaginary great Fault," and his question in the next page, as to how the Limestone has passed " over or under" the Fault, too well proves, that this Gentleman is but slightly acquainted, or rather not at all, whth my investigations, on the principles of Foults: but as this is a subject on which I must further enlarge, I shall introduce the same in a future Letter, and remain

Your obedient servant, 16 th July, 1813.

John Farey Sen. 